\title{
In Vitro Efficacy of Five Biofungicides against Rhizoctonia solani Kuhn in Rice
}

\author{
Irish Mae Bauzon-Cantila ${ }^{1 *}$, Jaime C. Silvestre ${ }^{2}$, Raquel B. Evangelista ${ }^{2}$, Edralyn \\ Catubay $^{2,3}$ \\ ${ }^{1}$ Graduate School, University of Southern Mindanao \\ ${ }^{2}$ College of Agriculture, University of Southern Mindanao \\ ${ }^{3}$ Institute of Agriculture and Related Sciences, Davao del Sur State College \\ Corresponding author: bauzon.irishmae@gmail.com
}

\section{ABSTRACT}

Rhizoctonia solani Kuhn, the causal pathogen of sheath blight is second most damaging fungal disease in rice. While using chemical fungicides present high detriment to environment, the study investigate the efficacy of treatments composing five biofungicides in three different rates along with a biological agent, chemical check and untreated against the pathogen in in vitro level. In vitro efficacy showed that Melaleuca alternifolia + terpenes at $3.00 \mathrm{ml} / \mathrm{L}$ of $\mathrm{H}_{2} 0$ (T6),

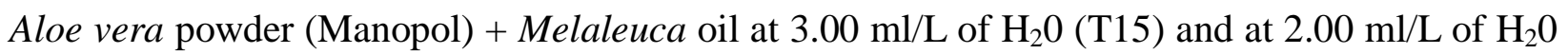
(T14) and Melaleuca alternifolia + terpenes at $2.00 \mathrm{ml} / \mathrm{L}$ of $\mathrm{H}_{2} 0$ (T5) as very effective (0-10 mm diameter zone of growth) treatments comparable to the chemical check (T17). Therefore, attaining high yield rice while having low risk to environment can always be done.

KEYWORDS: Aloe vera, Melaleuca, Biofungicides, rice sheath blight

\section{INTRODUCTION}

Rhizoctonia solani Kuhn, causing sheath blight is one of the most economically important fungal diseases that limits rice production [1], which its sclerotia or hyphae can easily attach to the rice sheath and infecting blight in rice [2]. Further infections are caused by hyphae growing upward towards uninfected plant parts and produce additional lesions and sclerotia on leaf sheaths affecting productivity in plants [3,4]. Depending on the plant stage upon infection and type of environment, a range of 4 to $50 \%$ can be reduced to the yield, making sheath blight as the second most damaging fungal disease in rice $[1,5-8]$. 
Rice released varieties such as hybrid rice and foreign germplasm with low resistance to sheath blight [9] had been tested to high rainfall areas in the Philippines [10, 11], which is a disease prone environment. It could be advantageous then to apply biofungicides to the crop. Biofungicides as one of the methods that can manage the disease is gaining popularity because it is more environment-friendly $[12,13]$. Moreover, regulations towards utilizing chemical fungicides could be stricter in the future as several organizations are putting pressure on taking out hazardous chemicals in the market [13]. Hence, this study was conducted to investigate the in vitro efficacy of biofungicides against $R$. solani Kuhn in rice.

\section{MATERIALS AND METHODS}

\section{INOCULUM AND TREATMENT PREPARATION}

Diseased sheaths of rice due to blight were collected in the field (Figure 1) and placed into plastic bag for diagnosis and isolation. Potato dextrose agar (PDA) was then used as medium for isolating sheath blight pathogen with the following components: $200 \mathrm{~g}$ of clean potato, $1 \mathrm{~L}$ of water, $20 \mathrm{~g}$ dextrose, and $20 \mathrm{~g}$ agar. The medium was dispensed in flat bottles, plugged with cotton and autoclaved at $15 \mathrm{psi}$ or $121^{\circ} \mathrm{C}$ for $15-30$ minutes. Tissue planting technique was used to transfer pathogen in PDA medium, which was incubated under room condition. Purification was done by transferring mycelial bits onto fresh PDA medium.

A total of 18 treatments composed of five biofungicides in three different rates, a biological control, chemical check, and untreated was used. The main component of the five biofungicides is Bacillus subtilis, Melaleuca alternifolia + terpenes, seaweed extract, Lactobacillus plantarum, aloe vera powder (Manopol) + Melaleuca oil. Trichoderma spp. was used as biological agent while Propiconazole + difenoconazole as chemical check. Other details of each treatment can be found in Table 1 .

BIOASSAY TEST

In a 14 days old $R$. solani Kuhn culture (Figure 2), culture disc method was used for fungicidal assay with the following steps in Figure 3. Petri plates were rotated thoroughly for mixing and congealing. Culture disc of the pathogen was placed at the center of the plates, which were labelled and incubated in inverted position under room temperature. Measurement of the diameter zone of growth (mm) of the pathogen was done after 72 hrs of incubation. 
The in vitro test was laid-out in completely randomized design with 18 treatments in triplicates. The data gathered was diameter zone of growth (DZG), which is a measurement to determine the efficacy of treatment. The data $(\mathrm{mm})$ was taken after 72 hrs of incubation, which efficacy follows an arbitrary scale range: 0-10 $\mathrm{mm}$ is very effective, 11-20 $\mathrm{mm}$ is effective, 21$30 \mathrm{~mm}$ is moderately effective, and $31 \mathrm{~mm}$ and above is not effective. The analysis of variance and mean separation were done using Statistix 9.0 [14].

\section{RESULTS AND DISCUSSION}

In vitro result showed the mean DZG $(\mathrm{mm})$ of $R$. solani Kuhn was significantly affected by the application of different rates of five biofungicides after $72 \mathrm{hrs}$ of incubation (Table 2). The most effective biofungicide was Melaleuca alternifolia + terpenes at $3.00 \mathrm{ml} / \mathrm{L}$ of $\mathrm{H}_{2} 0$ (T6) with no observed growth of the pathogen (Figure 4). Aloe vera powder (Manopol) + Melaleuca oil at $3.00 \mathrm{ml} / \mathrm{L}$ of $\mathrm{H}_{2} \mathrm{O}$ (T15) with $0.17 \mathrm{~mm}$ and at $2.00 \mathrm{ml} / \mathrm{L}$ of $\mathrm{H}_{2} \mathrm{O}$ (T14) with $2.17 \mathrm{~mm}$ and Melaleuca alternifolia + terpenes at $2.00 \mathrm{ml} / \mathrm{L}$ of $\mathrm{H}_{2} \mathrm{O}$ (T5) with $3.83 \mathrm{~mm}$ followed as among the most effective treatments (Figure 4). The effect of Melaleuca alternifolia + terpenes (T5 and T6) and Aloe vera powder (Manopol) + Melaleuca oil (T14 and T15) were comparable to the chemical check (T17) and rated as very effective (Figure 4). This implies that these two biofungicides were as effective as the chemical check in inhibiting the growth of $R$. solani Kuhn in vitro.

Previous reports showed that Aloe vera powder (Manopol) + Melaleuca oil effectively controlled Corynespora leaf fall disease of rubber caused by Corynespora cassiicola in in vitro study [15] while Melaleuca alternifolia + terpenes was found effective against Pythium aphanidermatum on pepper [16] and effectively control diseases Citrus madurensis [17]. The lowest rates at $1.00 \mathrm{ml} / \mathrm{L}$ of $\mathrm{H}_{2} 0$ of Melaleuca alternifolia + terpenes (T4) and Aloe vera powder

87 (Manopol) + Melaleuca oil (T13) were still rated effective, similar to the effect of lowest rate of

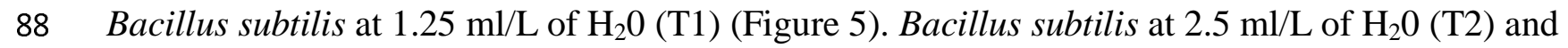
$3.75 \mathrm{ml} / \mathrm{L}$ of $\mathrm{H}_{2} \mathrm{O}$ (T3) were rated as moderately effective (Figure 6). Lastly, the three rates of 
91 from 40.83 to $66.83 \mathrm{~mm}$ and their results were comparable to the untreated control and

92 biological check with DZG means of 68.33 and $51.67 \mathrm{~mm}$, respectively (Figure 7).

\section{CONCLUSION}

97 promoted to uphold a safer environment.

98

\section{ACKNOWLEDGEMENTS}

100

The authors would like to thank Department of Plant Pathology, College of Agriculture

101 for allowing the utility of laboratory equipment.

102

103

STATEMENT ON CONFLICT OF INTEREST

104

The authors declare no conflict of interest.

105

106

107

108

109

110

111

112

113 


\section{TABLES AND FIGURES}

121

122 Table 1. Biofungicides and their corresponding details that has been used in the study.

\begin{tabular}{|c|c|c|c|c|}
\hline Component & $\begin{array}{l}\text { Commercial } \\
\text { name }\end{array}$ & Reports & Source & $\begin{array}{l}\text { Treatment } \\
\text { (rate*) }\end{array}$ \\
\hline \multirow{3}{*}{ Bacillus subtilis } & \multirow{3}{*}{ Seranade 250} & \multirow{3}{*}{$\begin{array}{l}\text { suppresses club root to canola } \\
\text { on in vitro conditions and } \\
\text { effective against crop damaging } \\
\text { pathogens like powdery } \\
\text { mildew, walnut blight and } \\
\text { Botrytis bunch rot and fire } \\
\text { blight }\end{array}$} & \multirow{3}{*}[18,19]{} & $\mathrm{T} 1(1.25 \mathrm{ml})$ \\
\hline & & & & $\mathrm{T} 2(2.5 \mathrm{ml})$ \\
\hline & & & & $\mathrm{T} 3(3.75 \mathrm{ml})$ \\
\hline \multirow{3}{*}{$\begin{array}{l}\text { Melaleuca } \\
\text { alternifolia }+ \\
\text { terpenes }\end{array}$} & \multirow{3}{*}{ Timorex Gold } & \multirow{3}{*}{$\begin{array}{c}\text { having prophylactic and } \\
\text { curative activity against broad } \\
\text { spectrum of diseases in crops }\end{array}$} & \multirow{3}{*}[20]{} & $\mathrm{T} 4$ (1 ml) \\
\hline & & & & $\mathrm{T} 5(2 \mathrm{ml})$ \\
\hline & & & & T6 (3 ml) \\
\hline \multirow{3}{*}{ Seaweed extract } & \multirow{3}{*}{ MPQ } & \multirow{3}{*}{$\begin{array}{l}\text { produces metabolites with } \\
\text { antiviral, antiprotozoal, } \\
\text { antifungal, and antibacterial } \\
\text { properties aiding in the } \\
\text { protection }\end{array}$} & \multirow{3}{*}{$\begin{array}{l}{[21,} \\
22]\end{array}$} & T7 $(0.25 \mathrm{~g})$ \\
\hline & & & & $\mathrm{T} 8(0.5 \mathrm{~g})$ \\
\hline & & & & T9 (0.75 g) \\
\hline \multirow{3}{*}{$\begin{array}{l}\text { Lactobacillus } \\
\text { plantarum }\end{array}$} & \multirow{3}{*}{ EM-1 } & \multirow{3}{*}{$\begin{array}{l}\text { produce antifungal substances } \\
\text { such as benzoic acid, } \\
\text { methylhydantoin, } \\
\text { mevalonolactone against plant } \\
\text { pathogens }\end{array}$} & \multirow{3}{*}[23-25]{} & $\mathrm{T} 10(1 \mathrm{ml})$ \\
\hline & & & & $\mathrm{T} 11(2 \mathrm{ml})$ \\
\hline & & & & $\mathrm{T} 12(3 \mathrm{ml})$ \\
\hline \multirow{3}{*}{$\begin{array}{l}\text { Aloe vera powder } \\
\text { (Manopol) }+ \\
\text { Melaleuca } \text { oil }\end{array}$} & \multirow{3}{*}{ AZ 41} & \multirow{3}{*}{$\begin{array}{l}\text { effectively control diseases and } \\
\text { insect pests in citrus }\end{array}$} & \multirow{3}{*}[17]{} & $\mathrm{T} 13$ (1 ml) \\
\hline & & & & $\mathrm{T} 14$ (2 ml) \\
\hline & & & & $\mathrm{T} 15(3 \mathrm{ml})$ \\
\hline Biological control & $\begin{array}{l}\text { Trichoderma } \\
\text { spp. }\end{array}$ & $\begin{array}{c}\text { induce systemic resistance } \\
\text { against plant pathogens }\end{array}$ & {$[26]$} & $\mathrm{T} 16(0.5 \mathrm{ml})$ \\
\hline $\begin{array}{l}\text { Propiconazole }+ \\
\text { difenoconazole }\end{array}$ & Armure & $\begin{array}{l}\text { controls Rhizoctonia solani } \\
\text { Kuhn in rice very effectively }\end{array}$ & {$[27,28]$} & $\mathrm{T} 17(1 \mathrm{ml})$ \\
\hline \multicolumn{4}{|c|}{ Untreated } & $\begin{array}{c}\text { T18 } \\
\text { (Untreated) }\end{array}$ \\
\hline
\end{tabular}


*diluted in $\mathrm{L}$ of $\mathrm{H}_{2} \mathrm{O}, \mathrm{MPQ}=$ Marvelous Premium Quality, $\mathrm{EM}=$ effective microorganism

Table 2. Diameter zone of growth $(\mathrm{mm})$ of $R$. solani Kuhn as influenced by different rates of biofungicides

\begin{tabular}{|c|c|c|}
\hline Treatments & Mean $(\mathrm{mm})^{1}$ & Degree of Effectiveness \\
\hline T1 & $18.17^{\text {cde }}$ & Effective \\
\hline T2 & $20.50^{\text {bcde }}$ & Moderately effective \\
\hline T3 & $22.17^{\text {bcde }}$ & Moderately effective \\
\hline T4 & $14.83^{\text {de }}$ & Effective \\
\hline T5 & $3.83^{\mathrm{e}}$ & Very effective \\
\hline T6 & $0.00^{\mathrm{e}}$ & Very effective \\
\hline T7 & $53.17^{\mathrm{ab}}$ & Not effective \\
\hline T8 & $66.83^{\mathrm{a}}$ & Not effective \\
\hline T9 & $48.83^{\mathrm{abcd}}$ & Not effective \\
\hline T10 & $44.00^{\mathrm{abcd}}$ & Not effective \\
\hline T11 & $40.83^{\mathrm{abcd}}$ & Not effective \\
\hline T12 & $41.33^{\mathrm{abcd}}$ & Effective \\
\hline T13 & $20.33^{\mathrm{bcde}}$ & Very effective \\
\hline T14 & $2.17^{\mathrm{e}}$ & Very effective \\
\hline T15 & $0.17^{\mathrm{e}}$ & Not effective \\
\hline T16 & $51.67^{\mathrm{abc}}$ & Very effective \\
\hline T17 & $0.00^{\mathrm{e}}$ & Not effective \\
\hline T18 & $68.33^{\mathrm{a}}$ & \\
\hline
\end{tabular}

${ }^{\mathrm{I}}$ Means in column followed by common letter superscripts are not significantly different at $1 \%$ level, Tukey's Test.

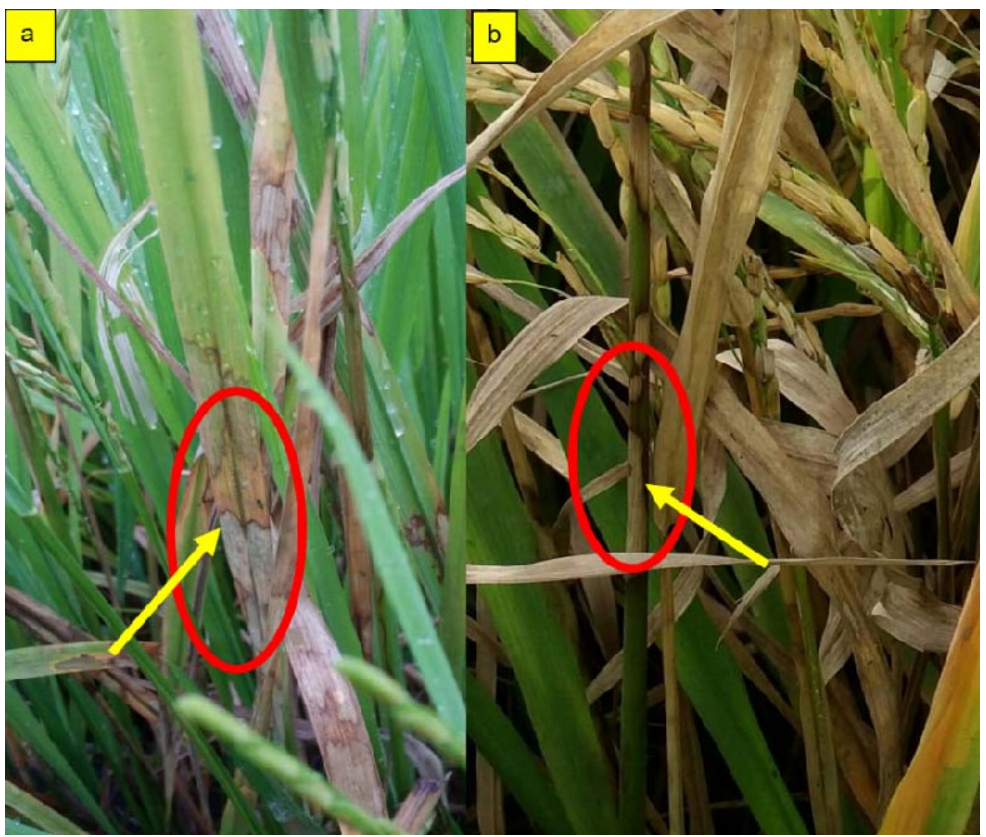


Figure 1. Rice plants showing symptoms of sheath blight on the (a) leaf (gray irregular lesions banded with green brown coloration and grayish center) and (b) sheath (oval gray spots with black brown margins that later enlarge).

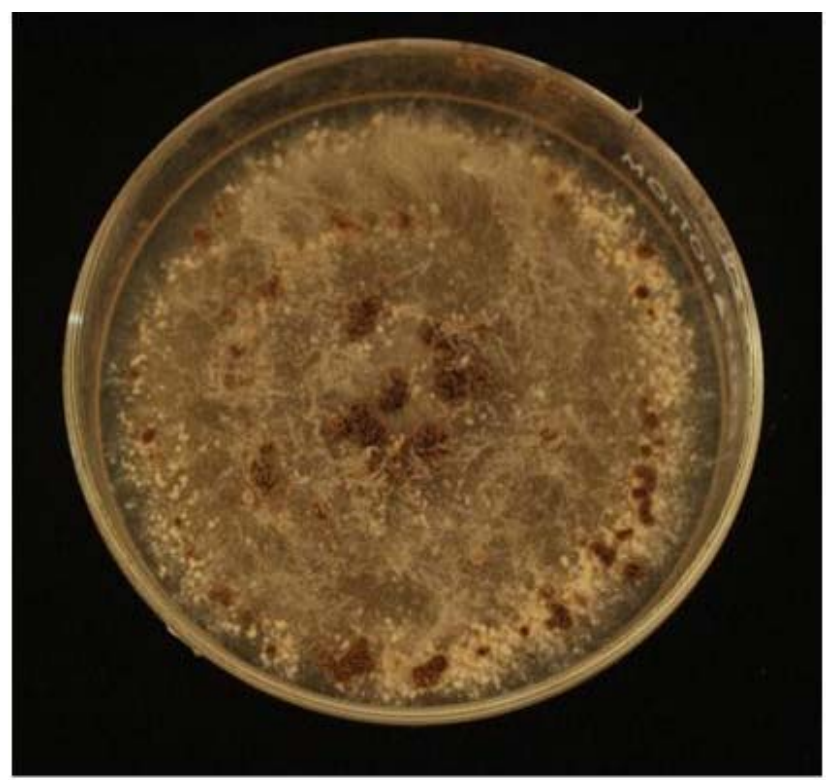

Figure 2. Pure culture of Rhizoctonia solani Kuhn in 14 days old showing mycelia and matured sclerotia on potato dextrose agar.
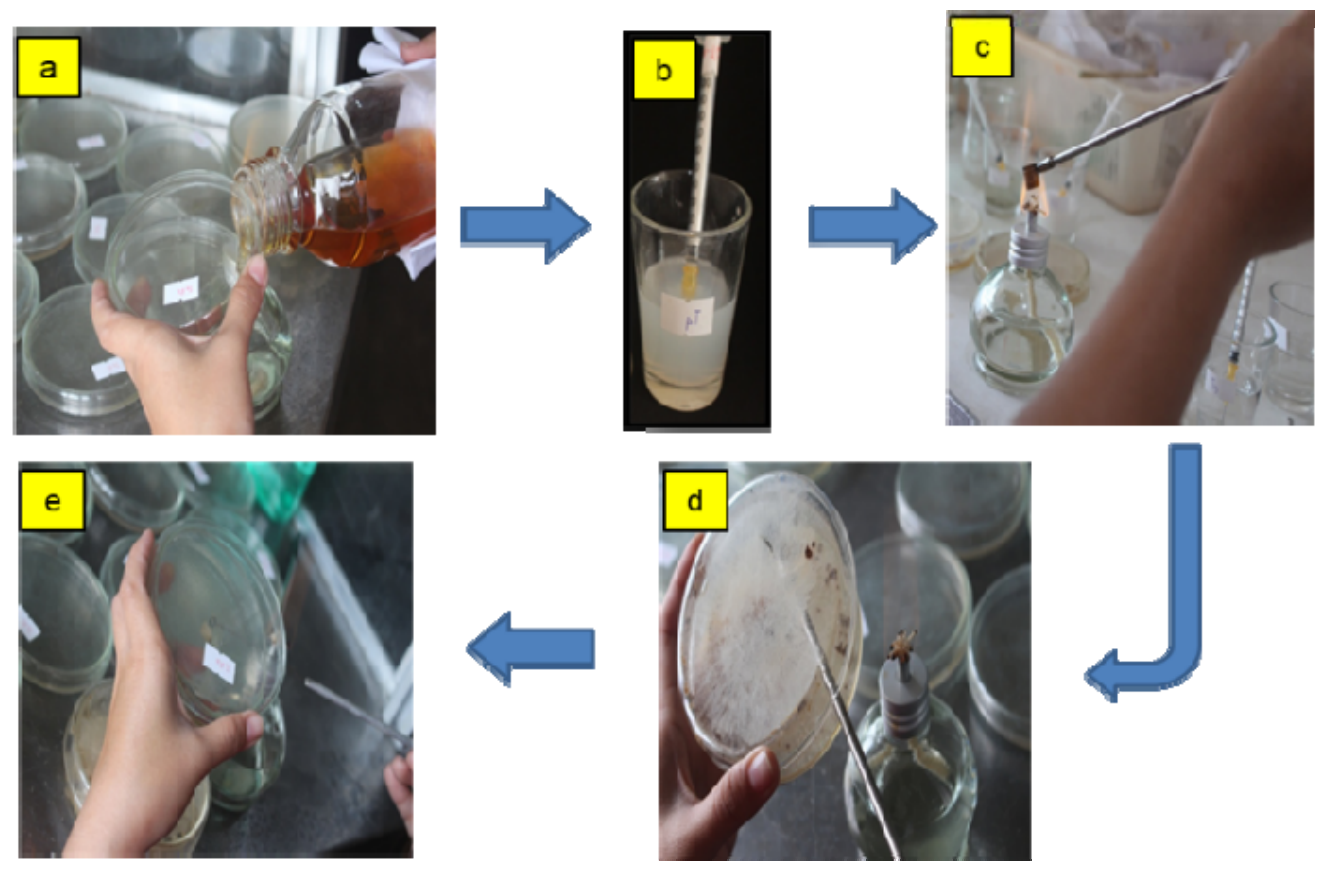

Figure 3. Culture disc method for biofungicidal assay of Rhizoctonia solani Kuhn. *a) Potato dextrose agar (PDA) was used as medium for isolating the pathogen, b) $1 \mathrm{ml}$ of the treatment was added to each petri plate with $20 \mathrm{ml}$ melted PDA, c) Ensure aseptic condition by flaming the 

pathogen was placed at the center of each plate.

145
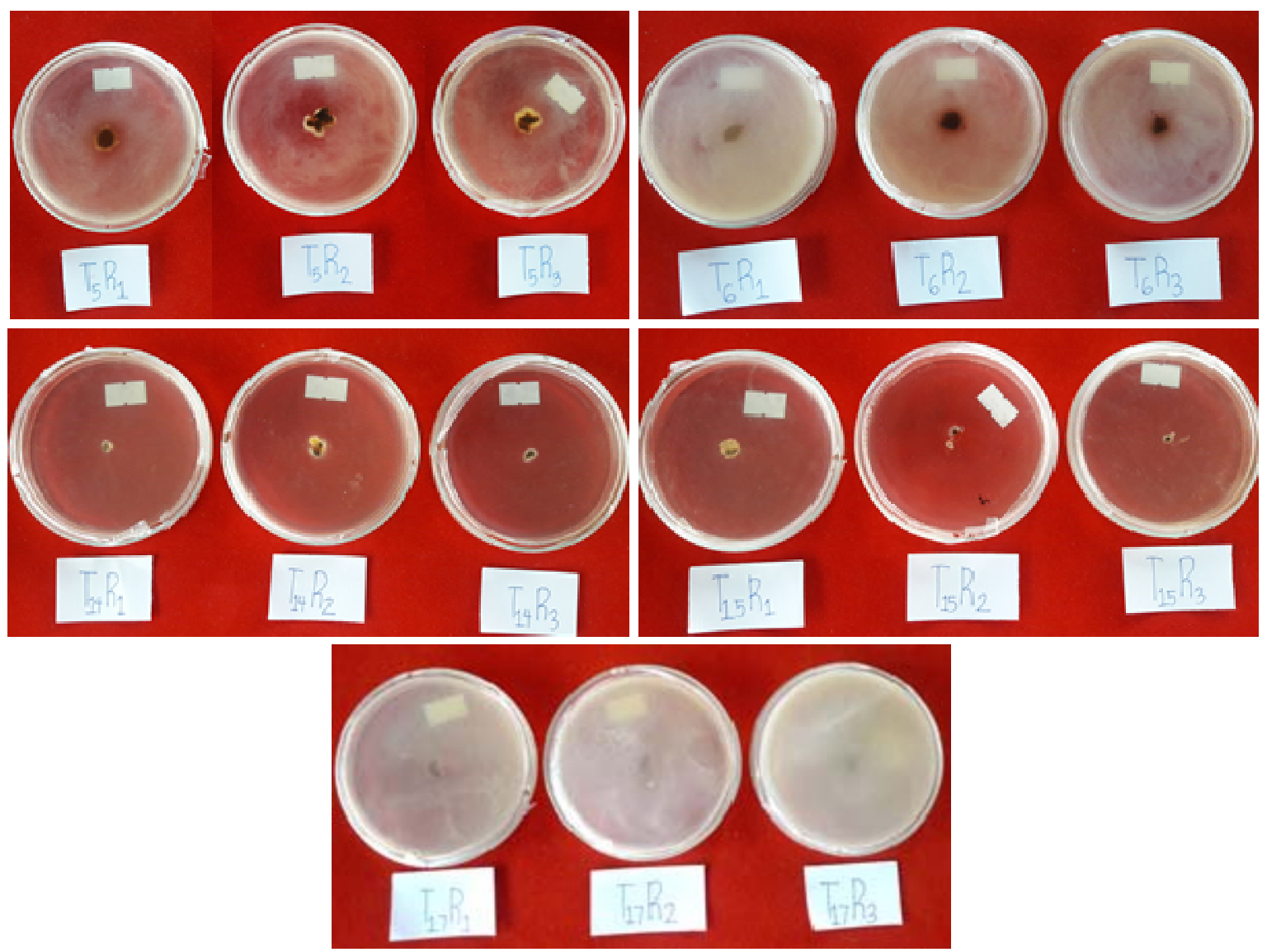

147 Figure 4. Diameter zone of growth of $R$. solani Kuhn showing very effective treatments in petri 148 dish. 

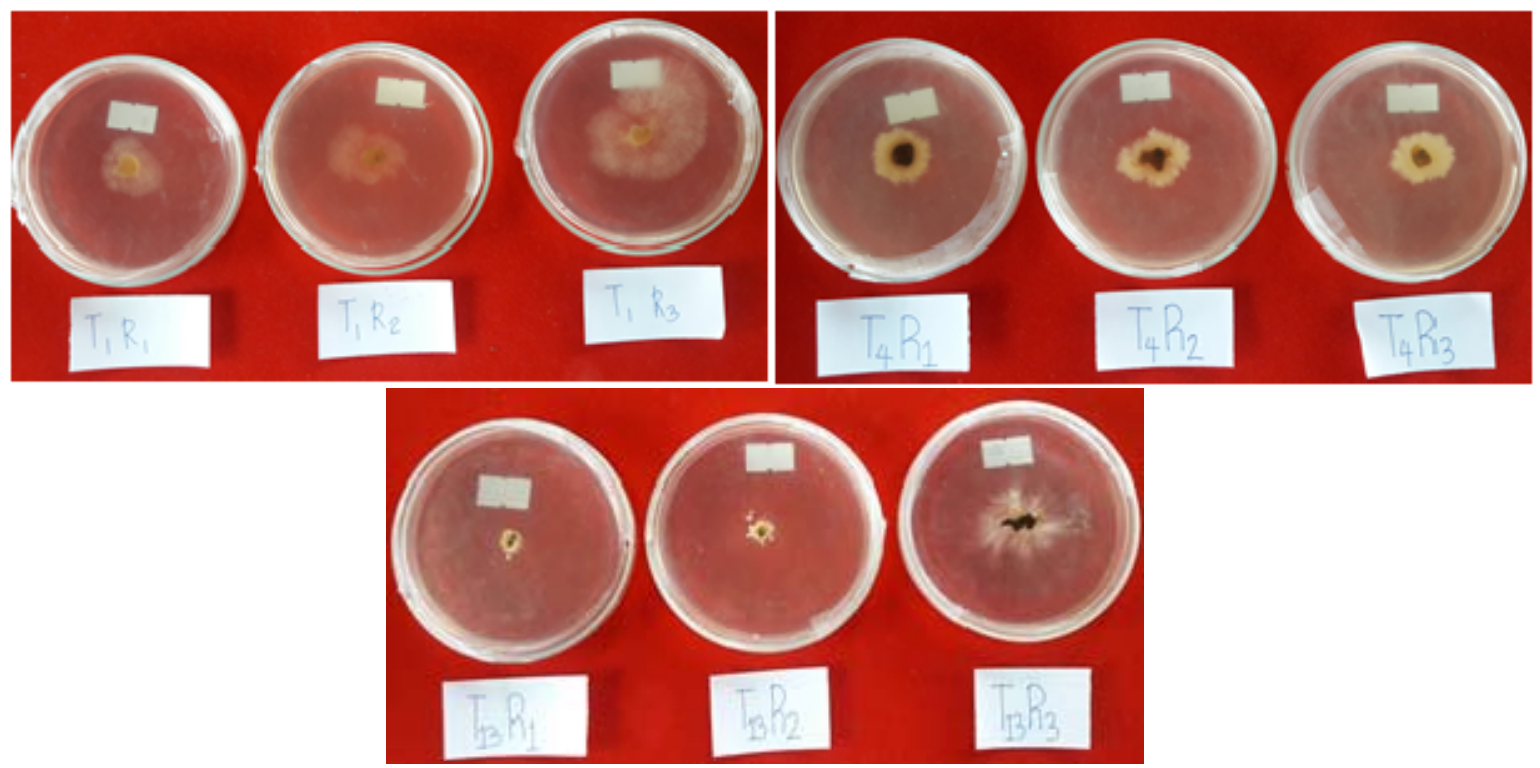

151 Figure 5. Diameter zone of growth of $R$. solani Kuhn showing effective treatments in petri dish.
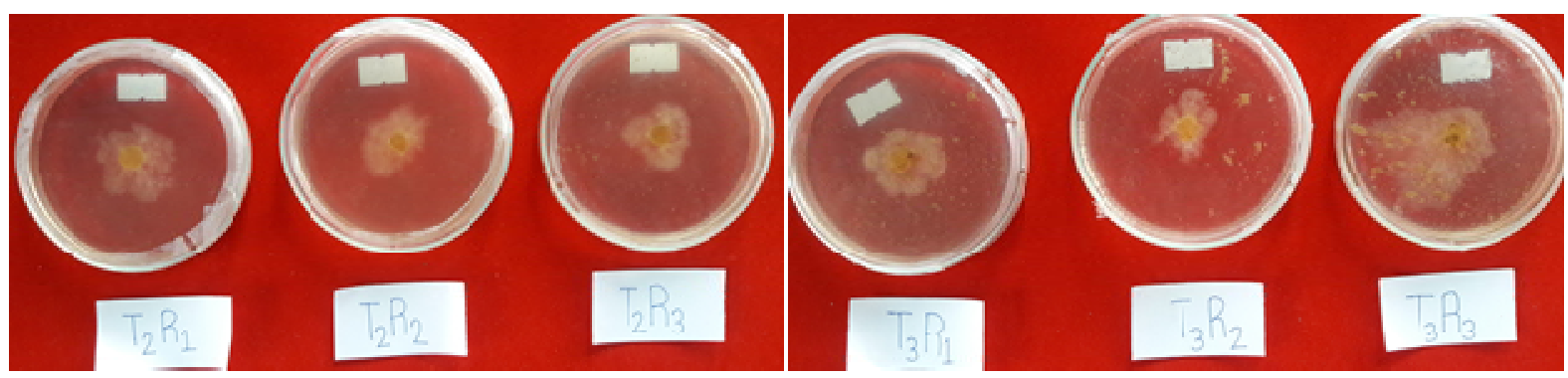

154 Figure 6. Diameter zone of growth of $R$. solani Kuhn showing moderately effective treatments. 

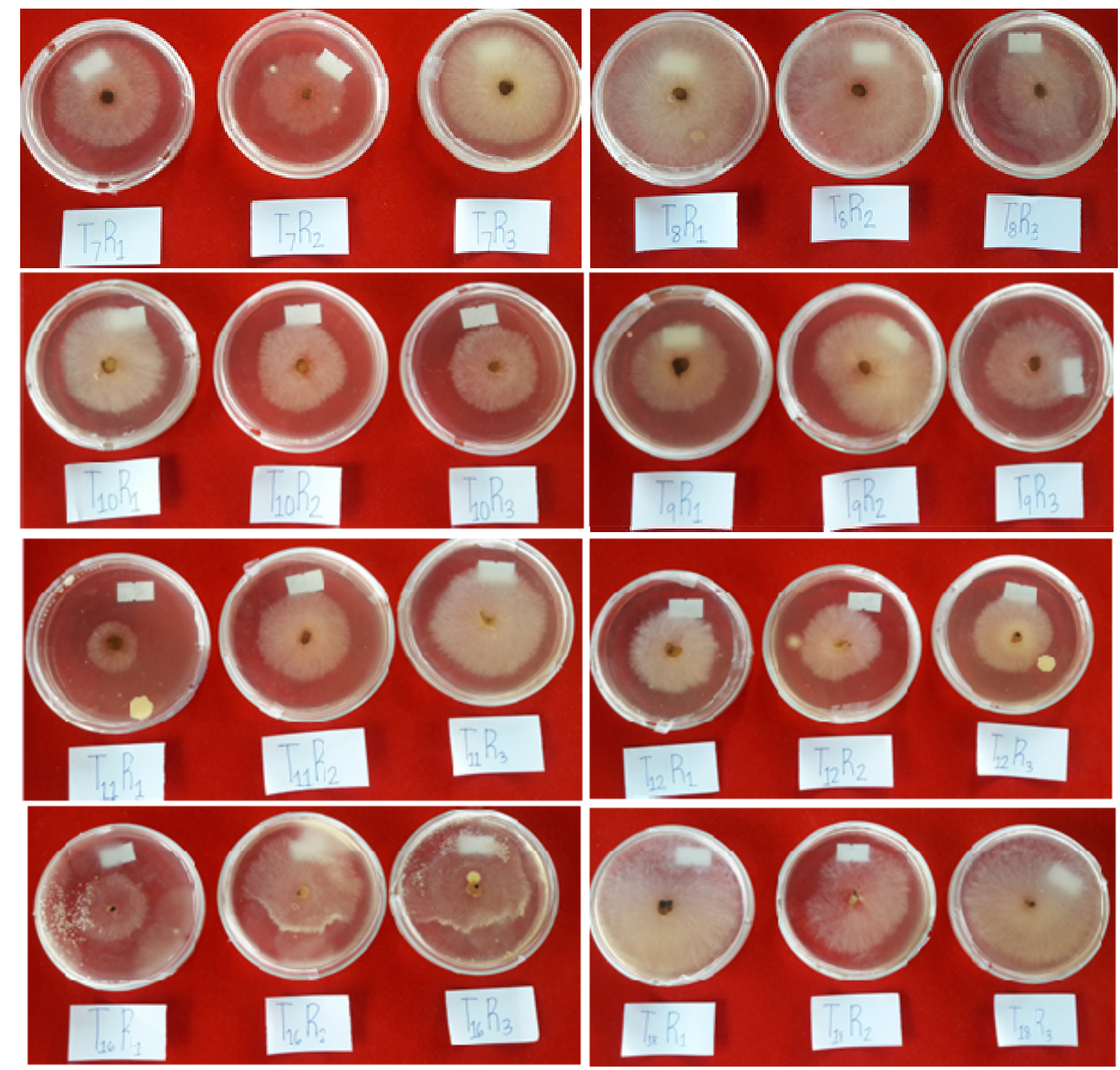

157 Figure 7. Diameter zone of growth of $R$. solani Kuhn showing not effective treatments.

\section{REFERENCES}

161

1. Molla, K.A., et al., Understanding sheath blight resistance in rice: the road behind and the road ahead. Plant biotechnology journal, 2020. 18(4): p. 895-915.

2. Singh, R., S. Sunder, and P. Kumar, Sheath blight of rice: Current status and perspectives. 2016. 69: p. 340-351.

3. Brooks, S.A., Sensitivity to a Phytotoxin from Rhizoctonia solani Correlates with Sheath Blight Susceptibility in Rice. Phytopathology, 2007. 97(10): p. 1207-1212.

4. Webster, R.K., Compendium of rice diseases. 1992: The American Phytopathological Society (APS).

5. Bhukal, N., R. Singh, and N. Mehta, Progression and development of sheath blight of rice in relation to weather variables J Mycol PI Pathol 2015. 45(2): p. 166-172. 
6. $\mathrm{Cu}, \mathrm{R}$., et al., Effect of sheath blight on yield in tropical, intensive rice production system. Plant Disease, 1996.

7. Singh, S.K., et al., Current status and impact of sheath blight in rice (Oryza sativa L.) - a review Agricultural Reviews, 2004. 25: p. 289-297.

8. Zheng, A., et al., The evolution and pathogenic mechanisms of the rice sheath blight pathogen. Nature communications, 2013. 4: p. 1424-1424.

9. https://www.pinoyrice.com/rice-varieties/. 12/01/2017].

10. Cantila, A. and A. Quitel, Statistical Analysis of Foreign Rice Phenotypes under Different Seasons of the Philippines. Journal of Advanced Applied Scientific Research, 2017. 1(12).

11. Cantila, A.Y., A.M.L. Fordan, and I.V. Boholano, Phenotypic variation and correlation of traits in Philippine hybrid rice varieties. J Bangladesh Agril Univ, 2019. 17(2): p. 179-186.

12. Alabouvette, C., C. Olivain, and C. Steinberg, Biological control of plant diseases: the European situation. European journal of plant pathology, 2006. 114(3): p. 329-341.

13. De Cal, A., et al., Use of Biofungicides for Controlling Plant Diseases to Improve Food Availability. Agriculture, 2012. 2(2).

14. Analytical-software, Statistix 9.0. 2009, Analytical software: Florida State University, PO Box 12185, Tallahassee, Florida 32317, USA.

15. Villanueva, J.D., et al., Management of Corynespora Leaf Fall Disease of Rubber in the Nursery. USM R\&D Journal, 2016. 24(1).

16. Mihajlović, M., et al., In vitro and in vivo toxicity of several fungicides and Timorex gold biofungicide to Pythuim aphanidermatum. Pesticidi i fitomedicina, 2013. 28(2): p. 117-123.

17. Tangonan, N., E. Butardo, and C.P. Kabacan, Effects of AZ41 organic foliar fertilizer on pests, diseases, and yield of calamansi (Citrus madurensis). Philippine Journal of Crop Science (Philippines), 2004.

18. Lahlali, R., et al., Evidence that the biofungicide Serenade (Bacillus subtilis) suppresses clubroot on canola via antibiosis and induced host resistance. Phytopathology, 2013. 103(3): p. 245-254.

19. Peng, G., et al., Potential biological control of clubroot on canola and crucifer vegetable crops. Plant Pathology, 2011. 60(3): p. 566-574.

20. STK, Timorex Gold, a broad spectrum fungicide, S.A.P. Incorporated, Editor. 2017, Stockton group: Unit 12 1st Floor, MSA Prime Center, Madrigal Business Park, Ayala Alabang, Muntinlupa City.

21. Kumari, S.S., V.D. Kumar, and B. Priyanka, Antifungal Efficacy of Seaweed Extracts Against Fungal Pathogen of Silkworm, Bombyx mori L. International Journal of Agricultural Research, 2017. 12: p. 123-129.

22. Pérez, M.J., E. Falqué, and H. Domínguez, Antimicrobial Action of Compounds from Marine Seaweed. Marine drugs, 2016. 14(3): p. 52.

23. Prema, P., et al., Production and characterization of an antifungal compound (3-phenyllactic acid) produced by Lactobacillus plantarum strain. Food and Bioprocess Technology, 2010. 3(3): p. 379-386.

24. Renuka, R. and B. Parameswari, Effective Microbes (EM) - An Organic Agricultural Technology. Research News for U, 2012. 9: p. 102-105.

25. Wang, H., et al., Activity against plant pathogenic fungi of Lactobacillus plantarum IMAU10014 isolated from Xinjiang koumiss in China. Annals of Microbiology, 2011. 61(4): p. 879-885.

26. Harman, G.E., Myths and dogmas of biocontrol changes in perceptions derived from research on Trichoderma harzinum T-22. Plant disease, 2000. 84(4): p. 377-393.

27. Chahal, K., S. Sokhi, and G. Rattan, Investigations on sheath blight of rice in Punjab. Indian Phytopathology, 2003. 56(1): p. 22-26. 
bioRxiv preprint doi: https://doi.org/10.1101/2020.07.22.216325; this version posted July 26, 2020. The copyright holder for this preprint (which

was not certified by peer review) is the author/funder, who has granted bioRxiv a license to display the preprint in perpetuity. It is made available under aCC-BY 4.0 International license.

218 28. Kandhari, J., Management of sheath blight of rice through fungicides and botanicals. Indian

219 Phytopathology, 2007. 60(2): p. 214-217.

220 